Blue, Morgan G. (Final Draft: June 2013)

Published with images in Film, Fashion \& Consumption Special Issue: TV \&

Fashion, Ed. Helen Warner, volume 2, number 1 (2013).

\title{
D-Signed for Girls: Disney Channel and Tween Fashion
}

During the 2010 back-to-school retail season, the Walt Disney Company introduced the first in a growing collection of fashion lines for tween girls under the umbrella label DSigned, available at Target stores throughout the United States. The initial line was based on the costumes of lead character Sonny Munroe of Sonny with a Chance (Marmel et al. 2009-2011), played by Demi Lovato. This was not Disney's first foray into fashion for pre-teen and teen girl markets. Previous lines include a multitude of character licensing deals throughout Disney's history and, more recently, a line inspired by Raven-Symoné's character Raven Baxter of That's So Raven (Poryes et al. 2003-2007), and fashion lines promoting Disney stars Miley Cyrus of Hannah Montana (Poryes and Peterman 20062011) and Selena Gomez of Wizards of Waverly Place (Greenwald et al. 2007-2012) as designers, not to mention Hilary Duff's independently produced fashion and consumer products collection, Stuff by Hilary Duff (2004). The introduction of the D-Signed collection, however, marks an unprecedented expansion of synergistic marketing strategies for comprehensive lifestyle branding to the tween girl market in the United States. The production and exponential growth of this particular fashion collection allow girls to literally (at Target stores or at home) and virtually (via sponsored online dress-up games and social networks) try on the 'edgy' fashions of Sonny Munroe, among other Disney Channel characters. Exploring the promotion of and inspiration for the D-Signed fashion collection can allow us to understand not only how fashion functions economically and ideologically in relation to convergent television as a site of lifestyle 
Blue, Morgan G. (Final Draft: June 2013)

Published with images in Film, Fashion \& Consumption Special Issue: TV \& Fashion, Ed. Helen Warner, volume 2, number 1 (2013).

marketing to tween girls, but also how contemporary girlhood is constructed in this arena of the Disney empire. Thus, this article asks, how might the D-Signed fashion collection function, discursively and economically, as a site for the reproduction and performance of a form of idealized, postfeminist tween girlhood? And how do fashion lines affiliated with Disney Channel programmes function within and beyond Disney's entertainment empire?

\section{Theoretical perspective and methodologies}

Throughout this article, girlhood signifies both a relation to commerce and a discursive subjectivity. This analysis follows Catherine Driscoll's understanding of the discursively constructed girl as 'encompassing no specific age group but rather an idea of mobility preceding the fixity of womanhood and implying an unfinished process of personal development' (2002: 47). The characters in Disney Channel programmes and promotions and their primary audiences are constructed as girls within the context of popular and commercial discourses, which position them as young-women-in-training. In addition to understanding girlhood as a category of constant 'becoming', however, it is necessary to clarify my references to the girls in Disney Channel audiences as also 'tweens'. The term tween is employed here to reign in the broad category of the girl, to foreground tensions between gender and generation and to focus on the ways in which girls are addressed who belong to that emergent market demographic of female-identified youths between the ages of about 8 and 14. Similar to the development of teen consumer culture in the 1950s, an increasing 'tween' population in the 1980s was, a decade later, eventually 


\section{Blue, Morgan G. (Final Draft: June 2013) Published with images in Film, Fashion \& Consumption Special Issue: TV \& Fashion, Ed. Helen Warner, volume 2, number 1 (2013).}

construed by marketing firms as the solidification of a new youth demographic worthy of recognition and in need of its own brand strategies (Kantrowitz and Wingert 1999). While early uses of the term by marketing professionals appear to have been gender neutral (see Hall 1987, for example), cultural shifts since the 1990s, including the increasing association of tween culture with fashion and beauty industries and girlfocused mass media - especially, I would argue, on Disney Channel since 2000 - have together led to the feminization of the term (Cook and Kaiser 2004). Much contemporary Disney Channel fare appeals to tween girl audiences, for instance, with fantasies of subjectification that operate through secret identities and overtly feminine disguises driven by girls' material consumption (Blue forthcoming). It is useful, then, to explore the ways in which the Disney conglomerate reproduces girlhood in relation to tween girls' participation in consumer fashion culture.

Fashion is a form of communication. As Roland Barthes explains, 'The wearing of an item of clothing is fundamentally an act of meaning that goes beyond modesty, ornamentation and protection. It is an act of signification and therefore a profoundly social act right at the very heart of the dialectic of society' (2006: 97). Writing in 1985, Annette Kuhn argued that we should understand dress as a form of masquerade in the performance of identity. Accordingly, Angela McRobbie has since asserted that contemporary culture promotes a 'postfeminist masquerade' for women to disguise feminist gains that might threaten the dominant heteronormative sex-gender system (2009). Women's prioritizing of consumption in order to maintain the stereotypically 


\section{Published with images in Film, Fashion \& Consumption Special Issue: TV \& Fashion, Ed. Helen Warner, volume 2, number 1 (2013).}

feminine appearance required by postfeminist culture results in the pervasive expectation that girls also will enact that masquerade of femininity by participating in particular ways in what Sandra Lee Bartky has called the fashion-beauty complex (Bartky 1990;

McRobbie 2009). Yet, the notion of the postfeminst masquerade may not be sufficient for understanding the relationship(s) between contemporary girlhood and the media and fashion industries.

I have argued elsewhere for an understanding of how Disney Channel's Hannah Montana employs a sort of postfeminist masquerade of 'girly-ness' for youth whose economic station is quite distinct from that of the women envisioned embodying the postfeminist masquerade in McRobbie's conceptualization (Blue forthcoming). For McRobbie, financially independent women, in particular, are expected to present themselves as sexually available and hyperfeminine in order to uphold what she calls the "new sexual contract' between men and women in contemporary society (McRobbie 2009). Girls cannot be easily grafted into this new sexual contract, however, since girlhood, perhaps especially in the United States, is constructed amidst complex negotiations between discourses of sexual objectification and discourses of asexuality and innocence. Girls may be expected to harness their femininity and sexual desirability from younger and younger ages, but their youth also subjects them to ideals of femininity that deny their sexuality. Valerie Walkerdine has argued that the eroticization of young girls is ubiquitous in popular media, as is public ignorance and denial of the phenomenon (Walkerdine 1998: 254). Girls may be expected, in postfeminist culture, to be 


\section{Blue, Morgan G. (Final Draft: June 2013) Published with images in Film, Fashion \& Consumption Special Issue: TV \& Fashion, Ed. Helen Warner, volume 2, number 1 (2013).}

hyperfeminine and to look sexually sophisticated, yet they may not be hailed as knowing participants in the masquerade. The pervasive influence of postfeminist discourse within girls' culture in the United States creates demand for close analysis and continued interrogation of Disney's strategies, ideologies, and products as the leading producer of media for girls.

The postfeminist masquerade relies on the notion that fashion might be used to purposefully create a false self in the service of patriarchy and traditional gender roles. Taking gender as performative rather than expressive, as Judith Butler has, 'there is no preexisting identity by which an act or attribute might be measured' (1990: 180). The 'authentic' self, then, is constituted in gender performativity, which is enacted through and on the body. As Jennifer Craik argues, "Our habitus of clothing creates a "face" which positively constructs an identity rather than disguising a "natural" body or "real" identity' (1994: 4). If fashion and dress are integral to identity - helping to generate subjectivity and social relationships - then girls' interactions with fashion must be understood as part of the work of identity formation and performance of self rather than as a practice of concealing the self. Nikolas Rose finds that "while our culture of the self accords humans all sorts of capacities and endows all sorts of rights and privileges, it also divides, imposes burdens, and thrives upon the anxieties and disappointments generated by its own promises' (1996: 5). Postfeminist culture seems to both 'take into account' and attempt to render invisible such divisions, burdens, anxieties and disappointments (McRobbie 2009). The D-Signed fashion collection cannot be understood simply a series 
Blue, Morgan G. (Final Draft: June 2013)

Published with images in Film, Fashion \& Consumption Special Issue: TV \& Fashion, Ed. Helen Warner, volume 2, number 1 (2013).

of youthful feminine costumes, then. Rather, it is a dynamic collection of products, inflected by the economic and political strategies of a global multi-media conglomerate, and it is a technology for girls' production and performance of the postfeminist self at the level of everyday practice.

Joanne Entwistle (2000), Sarah Street (2001) and Helen Warner (2012) each find that the study of mediated fashion has historically focused on film costume as disruptive spectacle or narrative device, privileging formal analysis. Warner suggests that, 'a mixed methodological approach to the study of costume... provides a more productive foundation upon which to begin to examine the functions of on-screen fashion in contemporary U.S. television' (2009: 183). Without losing sight of the tween girl audience, or of the distinct industrial and cultural intricacies of contemporary television, then, this analysis combines media industries research with discursive, narrative and ideological textual analysis. This article relies on a close reading of the promotional music video created to launch the initial D-Signed Sonny Munroe fashion line, as well as critical analysis of how Target, Disney Consumer Products (DCP) and Disney Channel personnel construct girls' fashion culture in their efforts to appeal to young female consumers and/or their parents/guardians. This video, the D-Signed apparel, and the promotional commentary regarding the D-Signed collection warrant examination as they exemplify the marketing techniques of the largest entertainment conglomerate in the world and operate as sites of production for conventions of femininity and western ideals of contemporary girlhood. How girls resist or negotiate Disney's ideological content and 
Blue, Morgan G. (Final Draft: June 2013)

\section{Published with images in Film, Fashion \& Consumption Special Issue: TV \& Fashion, Ed. Helen Warner, volume 2, number 1 (2013).}

conventions of femininity, as they surely do, is beyond the scope of this research. Rather, this article constitutes an exploration of how girlhood is constructed by and through the Walt Disney Company's strategies for appealing to girls with franchise properties originating on Disney Channel and extending, in this case, to fashion lines that reify certain television programmes and their characters as sites of identification meant to inspire girls' consumer and performative desires.

\section{Girls' fashion culture and feminine subjectivity}

Since the 1980s, teen and tween girls have been addressed as markets for hyperfeminine and sexually sophisticated consumer products. In particular, the fashion and beauty industries increasingly appeal to girls in ways that encourage agency within the realm of consumer choice and self-expression via physical appearance and adherence to trends and brand loyalty, if not designer label fetishism. McRobbie argues that fashion magazines function as sites of aspirational identification for young girls anticipating adolescence and womanhood (1991). Similarly, Daniel Cook and Susan Kaiser find that the sale of sexualized girls' apparel and its advertisement reflect the 'anticipatory enculturation' of tween girlhood (2004). For Cook and Kaiser, 'An aspirational social identity, the tween, by definition, seeks to move out of 'tweenhood' and thus up the age prestige ladder' (2004: 206). While the Disney Channel stars mentioned in this article are in their teens, the target audience for the network's prime-time fare is made up of girls who fall into one of two age ranges (8-12 or 9-14), referenced in D-Signed press releases as 'tween girls, sizes 4 to 16' (Business Wire 2010). DCP thus capitalizes on a long history of girls' 


\section{Blue, Morgan G. (Final Draft: June 2013) \\ Published with images in Film, Fashion \& Consumption Special Issue: TV \& Fashion, Ed. Helen Warner, volume 2, number 1 (2013).}

emulation of their favourite aspirational celebrities and performers (see Lewis 1990;

Stacey 1991; Douglas 1994; Kellner 1995; Lemish 1998; Baker 2004).

Disney promotions for D-Signed collections hail girls as subjects who might identify with specific characters or performers, but more frequently as those concerned with style and self-expression. They reinforce 'the norms of consumer society, which offers possibilities of a new commodity "self" through consumption and the products of the fashion industry' (Kellner 1995: 263). Thus, Disney Channel programmes and talent, and their related fashion lines, can easily function as part of a larger 'anticipatory enculturation' of girl consumer audiences. Yet, this consumerist strategy of enculturation does not necessarily rely on the anticipation of adolescence, adulthood or cultural visibility, as McRobbie reveals fashion magazines do. Instead, it offers the more immediate - fleeting, yet repeatable - material satisfaction of consuming popular trends of fashion and celebrity. Rather than anticipating their teen or adult selves, tween girls are expected to try on the styles and habits of older girls and women by engaging in similar fashion culture and consumption practices made possible by D-Signed.

Girls may not only aspire to look or be older - they may simultaneously aspire to certain qualities of character, talents and lifestyles, which the D-Signed fashion collection is designed to capture and convey. Executive vice president of global fashion and home for DCP, Pam Lifford states, 'Our D-Signed collection at Target... allows young girls to express their fashion sense with quality clothing at budget friendly prices' (Business Wire 2010). She describes the Sonny Munroe line in relation to girls' expressions of identity 


\section{Blue, Morgan G. (Final Draft: June 2013) \\ Published with images in Film, Fashion \& Consumption Special Issue: TV \& Fashion, Ed. Helen Warner, volume 2, number 1 (2013).}

and individuality. Yet she necessarily also refers to family budgetary concerns, since the commercial and industrial realities of these mass-produced, mediated fashions demand broad appeal and wide availability. Her gesture towards the family budget, as well as the partnership with Target itself, reveal that the line is geared towards middle-class and/or working-class consumers. While mentioning the 'budget-friendly prices' of the D-Signed collection illuminates DCP's need to appeal to girls' parents and guardians, it also implicates girls in their families' economic status, suggesting that girls themselves should be conscious of the financial exigencies of expanding girls' wardrobes. DCP can effectively hail girls' parents or guardians by addressing girls as autonomous individuals looking for expressive outlets via fashion who also desire to save their families money.

Connecting distinct characters, narratives and star texts with each fashion line creates a sense of variety within the collection and within the Disney Channel prime-time line-up. DCP (California, 2009), in partnership with Target Corporation (Minnesota, 1962; originally Dayton Dry Goods Co. 1902, then Dayton Hudson Corporation) and Jaya Apparel Group, LLC (California, 1982; previously L'koral, LLC), launched the two initial D-Signed lines in 2010 (the Sonny Munroe Collection) and 2011 (the Alex Russo Collection). Since then, the trio has launched fashion lines to accompany nearly every new Disney Channel live-action series featuring a teen or tween girl, in addition to seasonal updates to many lines and new lines affiliated with Disney Channel Original Movies. The breadth of the collection offers consumers multiple entry points and possibilities for identification, while allowing Disney Channel characters to constitute the 


\section{Blue, Morgan G. (Final Draft: June 2013) Published with images in Film, Fashion \& Consumption Special Issue: TV \& Fashion, Ed. Helen Warner, volume 2, number 1 (2013).}

parameters for each line. The collection simultaneously provides affordable, trendy clothing choices while also attempting to entrench girls and their parents/guardians within the Disney Channel brand by actively cultivating relationships between consumers and one or more transmedia franchise properties. Discourses of empowerment and individuality enacted through consumer choice and taste-based aesthetic distinctions are indicative of a postfeminist sensibility at work in contemporary culture (Gill 2007). The promise of individuation meant to be fulfilled via consumer decision-making, here, suggests a circumscribed form of 'empowerment' and identification for girl consumers. The choice between one or another D-Signed character line, or between one or another piece of apparel under the D-Signed umbrella, can function, then, as a strategy of containment within the on-going commodification of girlhood.

Girls adopt and adapt fashion culture - particularly the discourse of glamour — in ways that allow them to expand their sense of who they might be or could become. Jackie Stacey's study of women's and girls' fan practices reveals that teens, in particular, have historically identified with and celebrated their favourite film stars by mimicking their hair, make-up, and fashion style (1991). Similarly, Lisa Lewis’s study of Madonna and Cyndi Lauper 'wannabes' demonstrates the extent to which young female fans are willing to go in imitation of their favourite celebrities (1990). Even more relevant to this article is Farah Malik's study of the ways in which tween girls engage with fashion magazines to negotiate subjectivity through the construction of style and habits of consumption (2005). She finds that a girl's 'desire to be glamorous (stemming from magazine representations 


\section{Blue, Morgan G. (Final Draft: June 2013) Published with images in Film, Fashion \& Consumption Special Issue: TV \& Fashion, Ed. Helen Warner, volume 2, number 1 (2013).}

and messages)... can encourage [her] to "be all that she can be"... create aspiration and emulation... [and] broaden girls' world-views and sense of place by presenting possibilities for the attainment of success' (2005: 269, original emphasis). While consumerist aspirations in children's media are generally viewed by scholars as negative and limiting, Malik points out their possible benefits for girls. Contemporary Disney Channel programming and promotion is rife with references to stars and requests that girls 'shine', creating aspirational characters whose performances on and beyond the screen(s) make them celebrities.

Girls watching Disney Channel programmes, playing with D-Signed clothing in online dress-up games, or shopping the collection at Target stores are incessantly hailed by multiple branches of the Walt Disney Company to appear like the characters they see and also to perform like the stars who play them. According to Carol Dyhouse, over the past three decades as affluence has increased, 'glamour has become democratized and more available in the West' (2010: 195), but '[g]lamour is and probably always has been about fantasy, desire and longing' (2010: 204). Disney's pervasive aesthetic of sparkle and shine, in conjunction with its function as an aspirational girl-star machine, makes glamour an ever-present discourse in Disney media and products for girls. Even Disney's historical mythos of magic and enchantment speak to the original connotations of 'glamour' (Dyhouse 2010: 204). Focusing on teen media that features magic and witchcraft, Rachel Moseley has argued that the glamorous makeover is significant to feminine identity production and 'revealing of the pleasures and paradoxes at the heart of 
Blue, Morgan G. (Final Draft: June 2013)

\section{Published with images in Film, Fashion \& Consumption Special Issue: TV \& Fashion, Ed. Helen Warner, volume 2, number 1 (2013).}

the postfeminist project' (2002: 407). For D-Signed to drive Disney franchises towards their $\$ 1$ billion revenue goal, its glamorous appeal must be structured by celebrity fantasies and the Disney discourse of magic, but also by the practicalities of daily dress and everyday discount fashion for the tween girl audience.

In her discussion about the development of modern feminine style through the influence of popular cinema, Craik explains that,

Femininity was constructed as a process of selecting an ideal image and adapting available clothing and cosmetics to realize an approximation to that ideal. The attributes of femininity were also shaped by the practicalities of everyday life, particularly that of striking a balance between work and leisure. (1994: 74)

While celebrity culture and discourses of glamour significantly influence fashion, the practicalities of growing bodies, grade-school cultures, parental budgets, active leisure and online engagement also help to guide what will be fashionable for the tween girl market. Dawn Currie's study of teen girls' use of fashion magazines reveals that while girls go to lengths to describe their individual dress practices as distinct from others, school cultures dictate much of their wardrobes: 
Blue, Morgan G. (Final Draft: June 2013)

\section{Published with images in Film, Fashion \& Consumption Special Issue: TV \& Fashion, Ed. Helen Warner, volume 2, number 1 (2013).}

If girls want to be a recognizable member of a social group, they are required to dress in ways which make them recognizably similar to their friends $[\ldots]$ This does not mean that girls do not value experimentation or do not attempt to "be different"; rather, it means that individual creativity must fall within limits set by the group. (Currie 1999: 228)

Arguably, Disney Channel's characterizations of girlhood and the apparel designed for girls by DCP attempt to create a bound fashion universe for tween girls. Rather than developing a culture of dress that employs selective use of idealized fashions, the DSigned collection offers an evolving and expanding series of fashion lines conceptualized as complete everyday wardrobes. The press release announcing the initial line appeared in multiple outlets and referred to its 'mix-and-match versatility', specifying plans for updates to the line, as well as to the larger collection (Business Wire 2010). While girls' social groups may set the parameters for dress, here DCP and Disney Channel also play a role in generating a fashion culture around Disney Channel talent and characters, which, as I will explore further below, may also limit girls' creativity and experimentation.

\section{Popular television and the tween fashion paratext}

During the cartoon boom of the 1980s, toy companies created cartoon programmes that targeted boys and girls, ages three and older, as lucrative demographics 
Blue, Morgan G. (Final Draft: June 2013)

\section{Published with images in Film, Fashion \& Consumption Special Issue: TV \& Fashion, Ed. Helen Warner, volume 2, number 1 (2013).}

for the sale of action figures and other toys advertised both within the shows and in commercial breaks. Tom Engelhardt has called this 'the Strawberry Shortcake strategy' after the first successful cartoon with a licensed toy line tie-in (1986). Heather Hendershot understands these cartoons as part of what Marsha Kinder terms 'supersystems', since they function as 'networks of intertexuality' that 'cut across several modes of image production' and 'foster collectability' through successful commodification of multiple related products (Hendershot 1998: 98-99; Kinder 1993: 122-23). Disney, in particular, engages in synergistic cross-platform efforts to reach children, youth, and family audiences in this way. Such efforts are prevalent in contemporary media industries, but also have been found at work throughout the history of media production, such as in Mary Celeste Kearney's analysis of the first 'transmedia' franchises targeting girls, which traces this phenomenon back as far as the 1940s in the U.S. (Kearney 2004). Other scholars have referred to such texts as 'commercial intertexts' and 'franchise' properties, logics, or strategies (Meehan 1991; Jenkins 2004; Johnson 2011). These terms are useful for conceptualizing children's television in the post-network era as they convey the interdependence of different media platforms, types of media texts, and marketing strategies. Here, I refer to Disney's girl-driven transmedia franchises as a way of also calling attention to the ways in which Disney Channel narratives traverse the bounds of format and technology as part of the decades-long history of transmedia marketing. 
Blue, Morgan G. (Final Draft: June 2013)

\section{Published with images in Film, Fashion \& Consumption Special Issue: TV \& Fashion, Ed. Helen Warner, volume 2, number 1 (2013).}

From as early as the 1950s, children's television has incorporated product

advertisements, many of which were positioned as 'integral, or [advertisements] that were an extension of the shows themselves' and 'segues, or ones that linked the shows' segments together' and employed program actors as promoters (Alexander et. al. 1998: 8; See also McAllister 2005). But a significant increase in reliance on branding since the 1990s has led television networks to develop new strategies for relating to audiences (Johnson 2012). The contemporary Disney Channel live-action programmes that inspire the D-Signed lines may thus present a subtler, more insidious, form of marketing to tween girls than even the cartoons that doubled as toy commercials in the 1980s. John Thornton Caldwell's concept of "“relationship" branding' becomes useful here (Caldwell 2008: 245). Cable and broadcast networks have worked to develop affective relationships with their audiences by integrating digital technologies and the Internet into their marketing tactics (Caldwell 2008). For example, the major U.S. networks have customized and heavily branded websites with separate pages devoted to featured programs, which foster interactivity in a variety of ways. These sites may allow viewers to browse fashion and music that appear on the shows, to watch and comment on video clips from the shows and from behind the scenes, and to watch or read ancillary narratives that extend the life of some series.

Relationship branding efforts that employ digital media and technologies have allowed Disney to systematically build D-Signed fashion lines into its talent-driven transmedia franchises since 2010. Previous Disney Channel franchises have incorporated character 


\section{Blue, Morgan G. (Final Draft: June 2013) Published with images in Film, Fashion \& Consumption Special Issue: TV \& Fashion, Ed. Helen Warner, volume 2, number 1 (2013).}

or performer-specific fashion lines, including a line sold at Limited Too stores inspired by Lizzie McGuire (Minsky et al. 2001-2004, starring Hillary Duff) and Miley Cyrus’ and Max Azria's collection sold in Walmart stores in 2010. With D-Signed, though, these and other short-lived lines are displaced by a potentially unending supply of new and updated fashion lines that directly benefit the Walt Disney Company and its partners. President of Disney Channels Worldwide, Gary Marsh, stated in 2012 that, 'For most people who act, getting a television show is the end product... For us, it's the launch pad' (qtd. in Rose 2012). His job is not to produce programmes, 'it's to build franchises and stars' (qtd. in Rose 2012). The commercial imperative is clear in Marsh's perspective that the network is not just creating exceptional content. Disney Channel is nurturing aspirational stars via transmedia franchises designed to provide multiple, related revenue streams.

Eliding its commercial motives, Disney Channel distinguishes itself from other children's entertainment by avoiding product placement and advertising within and between programmes. This operating policy does have loopholes and exceptions, including occasional sponsorship advertisements for companies such as Sarah Lee, Dannon and Walmart. Regardless, Disney Channel maintains its reputation as a space seemingly free from the commercial imperatives of other television networks and the world beyond the diegesis. Even so, this cable network may function just as potently to simultaneously advertise many of the products DCP has to offer, by reproducing Disney principles and aesthetics on-screen and welcoming consumers into the Disney universe beyond the 


\section{Blue, Morgan G. (Final Draft: June 2013) Published with images in Film, Fashion \& Consumption Special Issue: TV \& Fashion, Ed. Helen Warner, volume 2, number 1 (2013).}

television screen, as they shop Disney products in familiar stores such as Home Depot, Bed, Bath \& Beyond, and Target, as well as on the Internet. Inasmuch as Disney does offer the fashions seen on Disney Channel for purchase by those who shop at Target, the programmes now can be understood also as de facto sites for product placement.

Disney Channel content has always been augmented by promotions for other Disney media via public service announcements and network branded bumpers, featuring Disney Channel talent. Yet, the results of much fine-tuning of Disney Channel's development of girl-focused franchises and the creation of DCP also paved the way for the D-Signed collection. Adweek reported in 2009 that, 'Disney says it has shifted from a strictly licensing business model to a consumer products firm capable of multifaceted strategies for innovation, quality and integrated branding efforts' (Polikarpov 2009). The Walt Disney Company had fully developed its consumer products division to take greater advantage of a growing licensing business, having moved into the arena of high fashion a few years before (Polikarpov 2009).

With Disney's new strategy and personnel firmly in place, DCP's mission also meshed well with Target's mantra, 'Design for All', and its commitment to partnerships with well-known designers of a wide variety of consumer goods. Vice President of Marketing, Simon Waters envisioned DCP as particularly capable of creating the type of designer merchandise Target specialized in selling: 'Collaborations with designers and manufacturers to create products are a priority for DCP... There isn't any other brand on the planet that can do what we do with authenticity' (Polikarpov 2009). The decision to 


\section{Blue, Morgan G. (Final Draft: June 2013) Published with images in Film, Fashion \& Consumption Special Issue: TV \& Fashion, Ed. Helen Warner, volume 2, number 1 (2013).}

work with Jaya Apparel Group is also significant, for although the D-Signed collections may be cheaply produced, Jaya Apparel Group has a reputation as the brand-builder that established 7 for All Mankind in the premium denim market and is the company that manufactures Mary-Kate and Ashley Olsen's high-end fashion line, among others. The D-Signed collection has been deftly branded, then, as both a series of overt Disney Channel referents and a design-conscious Target offering.

The fashion lines have thus also become significant paratextual elements in their respective girl-targeted franchises. In Show Sold Separately (2010), Jonathan Gray demonstrates the ways in which certain paratexts can vie for importance, both expanding upon and competing with primary media texts. His analysis of how playing with Star Wars action figures enhances audiences' interpretations of the films and how video games can offer viewers a chance to virtually enter the diegetic space of their related programmes and films suggests the potential of such products and texts to strengthen or alter relationships between audiences and media. His argument cannot be extended to the D-Signed lines, however, without considering also the function of lifestyle branding. Similar to relationship branding, lifestyle branding works to generate connections between consumer audiences and particular media and products. It relies on the expectation that viewers will assume or adapt certain on-screen identities by bringing the objects of the diegesis into their daily lives - through aspects of play and fantasy, certainly, but in this case also through the perhaps more mundane affairs of discount shopping and daily dress. Revealing the thrust towards lifestyle branding through girl- 
Blue, Morgan G. (Final Draft: June 2013)

\section{Published with images in Film, Fashion \& Consumption Special Issue: TV \& Fashion, Ed. Helen Warner, volume 2, number 1 (2013).}

centred sitcom franchises and fashion lines that began several years before the D-Signed launch, Managing Director of DCP Canada, Peter Noonan claimed in 2006 that, 'That's So Raven [2003] has transcended entertainment boundaries and now stands as a bona fide lifestyle brand for girls - encouraging them to express their sense of fashion and celebrate their unique style' (qtd. in Anon. 2006). Presenting fashion consumption as an opportunity to express individualism has become integral to the development of lifestyle brands for girls, and DCP personnel continually attempt to construct girls as autonomous, savvy consumers, all the while appealing also to their parents'guardians' pocketbooks (if not to the disposable income of girls themselves).

Disney's focus on versatility, availability and an effortlessly coordinated, yet practical, aesthetic drives home the notion that these clothes can be worn every day by many girls. Janna Fischer, a spokesperson for Target, reveals:

What's great about the collection is that it does [the layering] for you... what looks like a hooded sweater worn with a blazer over it is really only one piece. The hoodie and the jacket are sewn together but it gives the impression you are wearing both pieces. It makes accomplishing the style that the girls wear on the show very easy and affordable. You've effortlessly got the look. (McCarthy 2010) 


\section{Blue, Morgan G. (Final Draft: June 2013) Published with images in Film, Fashion \& Consumption Special Issue: TV \& Fashion, Ed. Helen Warner, volume 2, number 1 (2013).}

Such garments create a particular look 'effortlessly', with the goal of adapting the feminine ideals represented by Disney Channel characters and performers. But this collection may also limit the creative potential of daily dress and its mix-and-match possibilities by incorporating two garments into one. (Some skirts and shorts also have leggings attached.) The success of the D-Signed collection relies on the appeal of being able to incorporate glamour and celebrity emulation into everyday practices of dress.

\section{D-Signed online}

The $D$-Signed fashion lines are promoted by Disney online in several locations, including on Disney's websites and the Disney Living YouTube channel (established in 2009), as well as in the social network and dress-up games at StarDoll.com and on Target.com. The launch and continued promotion of the D-Signed fashions online calls attention to the ways in which this media conglomerate has come to understand the Internet as a site for developing and sustaining television audiences as also consumers of a multiplicity of other Disney texts, paratexts, experiences and products. If we understand television as a convergent medium (Jenkins 2006), especially in the current post-network era (Lotz 2007), then it is difficult to consider the cultural significance of Disney Channel programmes apart from their online iterations and paratexts. According to Sharon Marie Ross, in her study of television in the digital age, 'creating TV products that can thrive in different media forms, most crucially television and the Internet' is a key strategy for 
Blue, Morgan G. (Final Draft: June 2013)

\section{Published with images in Film, Fashion \& Consumption Special Issue: TV \& Fashion, Ed. Helen Warner, volume 2, number 1 (2013).}

networks (2008: 127). The daily presence of digital media in the lives of many girls necessitates an understanding of television that extends beyond the traditional home screen to its online iterations. Ross explains that, 'Corresponding to cross-platforming is the strategy of integrated ancillary products' (2008: 127). Since Disney Channel avoids airing commercial spots, its online marketing efforts have been integral to the relationship between contemporary fashion and television. Disney Channel has an active online hub for viewers at Disney.com, offers episodes on iTunes.com, and can promote particular programmes by association when promoting any of its girl performers on Disney Channel and Radio Disney. More importantly, DCP has taken advantage of multiple, interactive online outlets to promote the D-Signed collection from its inception, offering styling demonstrations, sneak peeks into upcoming lines, and fashion design tutorials augmented by links to StarDoll.com and Target.com for access to the D-Signed collection via Disney's 'Style Studio' and 'Fashion Lounge' pages.

Beyond the Disney websites, members of the StarDoll community at StarDoll.com can dress virtual paper dolls in D-Signed apparel, purchase the clothing for their avatars with StarDoll currency, add the fashions to wish lists for their dolls and for themselves, forward their D-Signed wish lists to family and friends via e-mail, and click through the StarDoll site to shop the D-Signed collection at Target.com. This encourages a degree of creative play with the clothing, while anchoring that play in the consumerist impulse, with all trajectories leading to the potential purchase - either virtual or material - of DSigned apparel. As one of the strategies used to market these fashions online, 


\section{Blue, Morgan G. (Final Draft: June 2013) \\ Published with images in Film, Fashion \& Consumption Special Issue: TV \& Fashion, Ed. Helen Warner, volume 2, number 1 (2013).}

StarDoll.com also works to extend an association between these everyday clothes and the luxury of designer fashions promoted and exhibited alongside the D-Signed collection on the site, as well as elsewhere in celebrity culture. (The site also promotes discourses of glamour through its focus on dressing celebrity avatars.)

In addition to the above online iterations, the D-Signed collection was launched using a video that circulated online via a DCP press release and at YouTube.com. YouTube users repeatedly refer to the launch video as the 'official' Demi Lovato music video for the song 'Me, Myself and Time' (Armato et al. 2010), but it competes for the title with a previously released, less fashion-oriented version of the video, which aired on Sonny with a Chance (11 April 2010) and also circulates online. The D-Signed version serves as both music video and clothing commercial, advertising not only its song, album, artist and record label as all music videos do, but also the first line in the D-Signed collection, its availability at Target stores, and its association with Disney Channel and Sonny with a Chance. It is most productive, then, to understand the D-Signed collection as part of a larger synergistic convergence of media, celebrity personae and products, keeping in mind the potential for girls' resistance and struggle at each point of interaction.

In the 'Me, Myself and Time' D-Signed video, Demi Lovato introduces the Sonny Munroe fashion line in a brief statement before the music begins, explaining that she loves to mix and match colours even when fashion dictates that they might not work together. Lovato's documentary-style introduction lays a foundation for the ways in which girls and their parents or guardians might interpret the Sonny Munroe line, 
Blue, Morgan G. (Final Draft: June 2013)

\section{Published with images in Film, Fashion \& Consumption Special Issue: TV \& Fashion, Ed. Helen Warner, volume 2, number 1 (2013).}

positioning Demi Lovato's own fashion sense as its impetus. Lovato's familiar voice and presence represent the line, with no reference to otherwise unknown DCP personnel or the costume designers for Sonny with a Chance. This sequence also delineates the DSigned mission as another opportunity for girls to express their individuality through dress. By presenting Lovato's style as inspiration for this fashion line, and by using the rhetoric of individuality and expression, DCP establishes Lovato as a privileged voice and likeness, capable of dictating fashion norms for her fans. Lovato is thus established as an articulate, confident and sophisticated style icon and someone who resists dominant fashion ideologies in favour of individual expression, while the music to 'Me, Myself and Time' dictates the movement and tempo of the video. Neither Lovato nor the cast or sets of Sonny with a Chance are the focus of the majority of the footage, though Sonny/Demi's voice, music and costumes drive the video. Lovato's brief 'talking-head' segment dissolves to the live-audience performance of Lovato's song on the set of Sonny with a Chance in which she plays piano and sings in character as Sonny Munroe. A few seconds later, the video cuts to a thin, White tween girl with long, straight brown hair, sketching at a desk in her bedroom, Lovato's performance clearly visible on the flat screen television beside her.

During the course of the video, the girl sketches designs for the D-Signed collection in her bedroom, then dances and struts with friends through school hallways exhibiting the various outfits, which change spontaneously on her body as she moves. The girl's agency as fashion designer, established at the outset of the video and re-established in the end, 
Blue, Morgan G. (Final Draft: June 2013)

\section{Published with images in Film, Fashion \& Consumption Special Issue: TV \& Fashion, Ed. Helen Warner, volume 2, number 1 (2013).}

makes her the protagonist of the video. Yet, the protagonist might also be the Sonny Munroe fashion line itself, as it completes a transition from live-action TV costume collection to the (White, upper-middle-class tween-aged) girl-next-door's everyday fare. The clothes come into play first as interactive sketches that flesh-out the fantasy of a vast wardrobe in a large mechanised closet, references to which abound in girls' media culture. For example, Hannah Montana features a room-sized, mechanized closet, while the prop and costume room and the girls' shared dressing room are key spaces in Sonny with a Chance. Even Disney Channel's newest animated princess, Sofia of Sofia the First, is presented with an expansive two-room closet filled with sparkling ball gowns upon moving into the palace (Mitchell 2013-present). In addition, backstage tour videos with Disney talent often focus on the wardrobe racks.

Figure 1: The expanding closet in the 'Me, Myself and I' video. Source: Screen capture; Disney Living Channel at YouTube.com. Copyright: Disney 2010. (INSERT IMAGE HERE)

Figure 2: The full closet in the 'Me, Myself and I' video. Source: Screen capture; Disney Living Channel at YouTube.com. Copyright: Disney 2010. (INSERT IMAGE HERE)

Figure 3: Selecting what to wear, using drawings. Source: Screen capture; Disney Living Channel at YouTube.com. Copyright: Disney 2010. (INSERT IMAGE HERE) 


\section{Blue, Morgan G. (Final Draft: June 2013) \\ Published with images in Film, Fashion \& Consumption Special Issue: TV \& Fashion, Ed. Helen Warner, volume 2, number 1 (2013).}

In this 'Me, Myself and Time' video, an over-the-shoulder shot reveals the girl unfolding paper flaps to expand her drawn closet, made up of four wide hanging bars and multiple shelves and drawers, full of clothes, as yet nondescript, in front of which a girl can be seen considering the options. When the page turns, the sketched girl stands front and centre, her body replaced by a pull-tab featuring some of the outfits she has drawn. The sketched outfits appear one after another, racing past as the artist pulls the tab, while the head and feet of the girl in the drawing remain static.

When she has decided on an outfit, the drawn girl marches down the stairs and out into the morning light. Appearing on her front porch, she is real - the artist who had been seated at the desk now stands in the sunlight.

In this fantasy, the presence of the clothes themselves, more than the act of choosing or designing them as a form of self-expression, bring the girl into being. The drawn girl, then, is a fantasy made temporarily real in the world beyond the bedroom through the invocation of apparel available at Target stores and featured on Disney Channel. Of the significance of fashion to identity, Pamela Church Gibson writes, '[f]ashion is a storehouse of identity-kits, of surface parts which, assembled, determine the interior essence' which is subsequently taken to determine the assemblage itself' (2000: 356). 


\section{Blue, Morgan G. (Final Draft: June 2013) Published with images in Film, Fashion \& Consumption Special Issue: TV \& Fashion, Ed. Helen Warner, volume 2, number 1 (2013).}

The girl in this video is constructed as a product of the clothing she designs and exhibits.

I do not wish to suggest a lack of self-awareness or reflexivity on the part of girl consumers or even this girl protagonist. Instead, I argue that the performative and unstable nature of contemporary girlhood identities allows for the clothing to 'make the girl', so to speak. For Kellner, 'in contemporary society, it may be more "natural" to change identities, to switch with the changing winds of fashion ... [suggesting] that identity can always be reconstructed, that one is free to change and produce oneself as one chooses' (1995: 243). If one might change her identity on a whim through consumer engagement, then appearing in D-Signed apparel - even without reference to the labour involved - can easily be construed as a form of postmodern identity production.

In the 'Me, Myself and Time' D-Signed video, fashion design and consumption are privileged over the processes of creative dressing as the key to girls' identity production. As in many television and film narratives, the act of shopping is elided in this video, and the generative process of dressing is reduced to a single choice. While avoiding a shopping montage helps foreground - perhaps especially for adult viewers and girls - the girl's agency and the confidence these clothes might offer, the superficiality of the creative process represented here masks the corporate nature of the fashion industry, which structures girls' agency. Rather than an act of imagination, dressing is simplified to a matter of choosing one composed outfit over another in a truncated array of options. As Elspeth Probyn has argued, 'In the West, choice is the benign bedrock of society. Be that in regard to the consumer imperative of choice to the all-pervasive political philosophy of 
Blue, Morgan G. (Final Draft: June 2013)

\section{Published with images in Film, Fashion \& Consumption Special Issue: TV \& Fashion, Ed. Helen Warner, volume 2, number 1 (2013).}

self-fashioning, it is not possible not to choose' (2008: 232). For Probyn, Anita Harris and others, the increased focus on 'at-risk' girls and young women in societies of the West under late capitalism has often meant the implication of girls and young women themselves in choosing their circumstances (Harris 2004; Probyn 2008). This reliance on individual choice is a key tenet of postfeminist culture and becomes central to marketing efforts that instead target 'can-do' girl consumers (McRobbie 2007; Harris 2004). In the case of D-Signed, such efforts suggest variety in order to present consumer choice as a necessary and normalizing expression of individuality - opting out is not an option.

With the 'Me, Myself and Time' video, DCP can suggest the variety and individuating power of the D-Signed collection and bolster a sense of girls' agency by positioning a girl as the fashion designer. The collection, the video implies, has been created not only for but also by girls — particularly, fans of Demi Lovato and Sonny with a Chance. But positioning the girl as creative talent in this way also makes her a vehicle for the video's elision of the actual labor of producing and consuming these fashions. The 'Me, Myself and Time' video contains no mention of either DCP or Jaya Apparel Group, the creative and industrial engines producing and promoting the D-Signed collection, let alone mention of many of the individuals and groups (other than Lovato and Disney Channel) who produced the video and song. And, with shopping and dressing occurring beyond the diegesis, the labour involved in getting the Disney 'look' is made invisible and maintained as seemingly effortless - a shared convention of both stereotypical 
Blue, Morgan G. (Final Draft: June 2013)

\section{Published with images in Film, Fashion \& Consumption Special Issue: TV \& Fashion, Ed. Helen Warner, volume 2, number 1 (2013).}

Hollywood glamour and conventional femininity (Dyer 1998; Dyhouse 2011; McRobbie

1991). In her analysis of the beauty pages of Jackie magazine, McRobbie argues:

In general $[\ldots]$ the emphasis is on two things, the end-product ('the look') and the means of achieving it. The fact that this depends on the consumption of special commodities is kept well in the background, so that the concept of beauty soars high above the mundanity of consumption. (1991: 120, original emphasis)

Similarly, this D-Signed launch video may present a creative and agential girl protagonist through whom the Disney Channel franchise machine can create aspirational, consumerist fantasies targeting the tween girl market.

If Disney's programmes and products address girls as citizens whose power lies primarily in consumer choice, then it is important understand both the representational politics at work and the aesthetic conventions that mark these decidedly postfeminist images of contemporary girlhood. Normative representations of femininity and White privilege overwhelm attempts to appeal to a diverse audience when, as the video continues, the fair-skinned D-Signed girl is joined by two friends of colour. These two girls are represented as objects of the mise-en-scène, balancing each other as they remain side-by- 


\section{Blue, Morgan G. (Final Draft: June 2013) Published with images in Film, Fashion \& Consumption Special Issue: TV \& Fashion, Ed. Helen Warner, volume 2, number 1 (2013).}

side, three steps behind the protagonist. As the D-Signed girl walks to school, she passes other smiling youths in Disney licensed T-shirts and apparel (easily distinguished by the familiar Mickey Mouse logo). She meets a friend and hugs her, before they launch a group dance up the steps of the building. In the style of a runway fashion show staged in middle-school hallways, she and her two girlfriends flaunt their trendy outfits, confident and smiling.

As Currie writes, 'Fitting into school culture means adopting not only the activities and behaviours of peers, but their distinctive modes of dress' (1999: 228). Here, the central girl is privileged as a sort of girl-next-door stand-in for Demi Lovato. The presence of her two friends in complimentary D-Signed apparel, make her recognizable as a potential trend leader and as someone who fits into her particular social group. As an unknown performer (none of the performers are credited in the video), she may also represent the accessibility of the line by suggesting that one does not have to be a Disney star to get the Disney 'look'. Further, her Whiteness displaces Lovato's Latina 'difference' in the video. Coded as White and middle-class, the girl designer's youth as well may allow her less physically developed body to appear less sexual and therefore non-threatening - more easily acceptable as a model for tween girlhood, perhaps especially in the eyes of protective parents/guardians.

The outfit featured early on in the 'Me, Myself and Time' video is frequently used to represent the Sonny Munroe fashion line, and is referred to, in the 'D-Signed Target Fact Sheet' that accompanied the initial press release, as the 'Picture Day Outfit' (Disney 


\section{Blue, Morgan G. (Final Draft: June 2013) Published with images in Film, Fashion \& Consumption Special Issue: TV \& Fashion, Ed. Helen Warner, volume 2, number 1 (2013).}

Consumer Products 2010). This labeling of the outfit links girls' school identities and girls' visibility to the D-Signed collection and Sonny Munroe. The outfit featured in this and other promotions of the Sonny Munroe fashion line consists of a yellow, grey, and black skirt with tulle edging, a black jacket with attached grey hoodie, a non-Disneyspecific graphic tee, cropped black leggings, a lapel pin and coordinated bracelets and necklaces. But there are other outfits in this collection too, and they appear spontaneously in the video on the central girl as she walks.

Flanked by her friends, one Asian and the other African American, this Caucasian girl is the only one whose outfits change. As she exhibits dresses, blazers, and a variety of accessories, her friends, treated more like back-up dancers, appear only in their respective coordinated outfits. Further, these two girls are depicted as interchangeable, alternately appearing on opposite sides of the White protagonist, though always in the same complimentary apparel and always behind her. The repeated and rhythmic appearance of the girls - dancing to Lovato's song, wearing Sonny's clothes - may represent D-Signed apparel as objects of creative self-expression and celebrity identification, but the objectifying power of the clothing to both privilege and commodify feminine, fashionconscious, middle-class White girlhood reveals the commercial thrust of the video long before the D-Signed and Target logos finally appear. The video may appeal to a diverse audience via aspirational representations of seemingly post-racial, normative middleclass White femininity, but it may also create a clear, and limited, picture of who the ideal D-Signed consumer is, as well as what her parents or guardians may want for her - 


\section{Blue, Morgan G. (Final Draft: June 2013) Published with images in Film, Fashion \& Consumption Special Issue: TV \& Fashion, Ed. Helen Warner, volume 2, number 1 (2013).}

to look trendy, to be the centre of attention at school, to feel happy and confident, to be popular (i.e. to be able to perform 'can-do' White, middle-class privilege in her everyday life). Representations of Whiteness and class privilege abound on Disney Channel as they have elsewhere on television since 1958, when 'urban, ethnic working-class programs' were initially eliminated from the schedule (Lipsitz 1992: 103). The significance of these particular representations, however, is that they use everyday fashion, celebrity culture, and popular television in synch to construct normative girlhood as a desirable commodity. The D-Signed girl is a 'can-do' girl, and an embodiment of postfeminist femininity and consumer empowerment (Harris 2004).

\section{Conclusion}

Deploying girls' images and performances, the Walt Disney Company is at the forefront of commercial enterprise that exploits discourses of girlhood in increasingly complex and problematic ways. As the conglomerate attends to girl consumers, now more pointedly than ever, it is impossible to ignore the relationships between contemporary girlhood, Disney Channel programming and its related texts and products. The quickly growing, successful D-Signed fashion collection constitutes seamless cross-promotion of apparel, Disney stars, their sitcoms and music, and the broader Disney lifestyle brand targeting young, female viewers of prime-time Disney Channel programming.

The economic and aesthetic parameters that delimit the D-Signed collection demand that we consider it as functionally different from the other products typically developed as 


\section{Published with images in Film, Fashion \& Consumption Special Issue: TV \& Fashion, Ed. Helen Warner, volume 2, number 1 (2013).}

paratexts related to children's programming. Dress can have subversive and expressive potential, but the repeated representation of the Sonny Munroe collection as a series of always/already well-crafted outfits may actually elide girls' agency by divesting dress of its expressive, generative potential. The D-Signed girl is not depicted trying on outfits, sharing or exchanging pieces. Instead her clothes change magically, layered, accessorised and fully composed outfits appearing on her frame at regular intervals. The 'Me, Myself and Time' video celebrates the end result of girls' creative and consumer choices, constrained by the D-Signed brand. Dubious as the mythology of identity and empowerment through consumer choice may be, it is telling that the processes of choosing and re-appropriating clothing are here subsumed within the display of professionally styled, complete outfits, restraining girls' enactments of power, which could allow them to challenge normative ideologies of femininity and youth.

While the functions of fashion in the Disney children's media empire can help us explore how Disney might influence contemporary discourses of US girlhood, market synergy cannot tell the whole story. It is important to reiterate the work that the D-Signed outfits do as costumes that can continually reference Disney Channel. But Craik argues for an understanding of fashion that moves beyond consumer culture, conceptualising it as 'a general technique of acculturation' that operates in everyday life through practices of dress (1994: 8). The Sonny Munroe line, as well as others in the D-Signed collection, must also be understood, then, as paratexts - as media forms and as technologies for bringing elements of particular Disney Channel diegeses into the lived experiences of 
Blue, Morgan G. (Final Draft: June 2013)

\section{Published with images in Film, Fashion \& Consumption Special Issue: TV \& Fashion, Ed. Helen Warner, volume 2, number 1 (2013).}

girls. As a result of this paratextual function, girls' practices of dress may be bound by the characterizations of the television content from which the apparel originates. Ultimately, it is the straightforward display of consumer fashion which functions as a supposed site of empowerment for the girls in the D-Signed launch video. In addition, DCP's and Target's promotional efforts implicate girls in the production and maintenance of Disney Channel's transmedia franchises. DCP and Target personnel attest to D-Signed's potential for allowing girls to express their individuality. Yet, the video used to promote the initial line, along with the economics and aesthetics of the collection itself, may work to limit the very creative and critical possibilities of girls' dress and identity-production that Disney aims to foster.

\section{References}

Alexander, Alison, Benjamin, Louise M., Hoerner, Keisha and Roe, Darrell (1998), “"We'll be back in a moment": A content analysis of advertisements in children's television in the 1950s', Journal of Advertising, 27:3, Autumn, pp. 1-9.

Anon. (2006), ‘That's So Raven “Eye on Fashion” Benefit Raises \$75,000 For Children’s Miracle Network', Business Wire, http://www.businesswire.com/news/home/2006092500 6231/en/Raven-Eye-Fashion-Benefit-Raises-75000-Childrens. Accessed 25 September 2006. 
Blue, Morgan G. (Final Draft: June 2013)

Published with images in Film, Fashion \& Consumption Special Issue: TV \& Fashion, Ed. Helen Warner, volume 2, number 1 (2013).

Armato, Antonina, James, Tim, and Karaoglu, Devrim (2010), 'Me, Myself and Time’, Song, on Sonny With a Chance, perf. Lovato, Demi, Burbank: Walt Disney Records.

Barthes, Roland (2006), The Language of Fashion, Trans. Stafford, Andy, New York: Berg.

Bartky, Sandra Lee (1990), Femininity and Domination: Studies in the Phenomenology of Oppression, New York: Routledge.

Baker, Sarah (2004), 'Pop (in)to the bedroom: Popular music in pre-teen girls' bedroom culture', European Journal of Cultural Studies, 7:1, pp. 75-93.

Blue, Morgan Genevieve (forthcoming), “"The Best of Both Worlds?” Youth, gender, and a postfeminist sensibility in Disney's Hannah Montana', Feminist Media Studies, $13: 4$

Business Wire (2010), 'Disney and Target Launch New “D-Signed” Tween Fashion Line', http://www.businesswire.com/multimedia/home/20100721005443/en/2065 818/Disney-Target-Launch-\%E2\%80\%9CD-Signed\%E2\%80\%9D-Tween-Fashion-Line. Accessed 21 July 2010.

Butler, Judith (1990), Gender Trouble: Feminism and the Subversion of Identity, New York and London: Routledge. 
Blue, Morgan G. (Final Draft: June 2013)

Published with images in Film, Fashion \& Consumption Special Issue: TV \&

Fashion, Ed. Helen Warner, volume 2, number 1 (2013).

Caldwell, John Thornton (2008), Production Culture: Industrial Reflexivity and Critical

Practice in Film and Television, Durham and London: Duke University Press.

Ching, Ross (2010), 'Me, Myself and Time’, video, Disney Living,

http://www.youtube.com/watch?v=CiTUlnvdy5Q. Accessed 20 September 2012.

Church Gibson, Pamela (2000), 'Redressing the Balance: Patriarchy, postmodernism and feminism', Fashion Cultures: Theories, explorations and analysis, in S. Bruzzi and P.

Church Gibson (eds), London: Routledge, pp. 349-362.

Cook, Daniel Thomas and Kaiser, Susan B. (2004), 'Betwixt and be tween: Age ambiguity and the sexualization of the female consuming subject', Journal of Consumer Culture, 4:2, pp. 203-27.

Craik, Jennifer (1994), The Face of Fashion: Cultural Studies in Fashion, London:

Routledge.

Currie, Dawn (1999), Girl Talk: Adolescent Magazines and Their Readers, Toronto: University of Toronto Press.

Disney (2011), 'Fashion Lounge', http://disney.go.com/officialsites/disney-fashionlounge/products. Accessed 20 November 2012. 
Blue, Morgan G. (Final Draft: June 2013)

Published with images in Film, Fashion \& Consumption Special Issue: TV \&

Fashion, Ed. Helen Warner, volume 2, number 1 (2013).

Disney (2011), 'Style Studio’, http://disney.go.com/makeyourmark/style-studio/.

Accessed 20 November 2012.

Disney Consumer Products (2010), 'D-Signed Target Fact Sheet',

http://disneyconsumerproducts.com. Accessed 20 May 2013.

Douglas, Susan J. (1994), Where the Girls Are: Growing up Female with the Mass

Media, New York: Three Rivers Press.

Driscoll, Catherine (2002), Girls: Feminine Adolescence in Popular Culture and Cultural Theory, New York: Columbia University Press.

Dyer, Richard ([1979] 1998), Stars, London: British Film Institute.

Dyhouse, Carol (2010), Glamour: Women, History, Feminism, London: Zed Books.

Engelhardt, Tom (1986), ‘Children's Television: The Shortcake Strategy’, Watching

Television: A Pantheon Guide to Popular Culture, in T. Gitlin (ed.), New York: Random

House, pp. 72-73.

Entwistle, Joanne (2000), The Fashioned Body: Fashion, Dress, and Modern Social

Theory, Cambridge: Polity Press. 
Blue, Morgan G. (Final Draft: June 2013)

Published with images in Film, Fashion \& Consumption Special Issue: TV \&

Fashion, Ed. Helen Warner, volume 2, number 1 (2013).

Gill, Rosalind (2007), Gender and the Media, Cambridge: Polity Press.

Gray, Jonathan (2010), Show Sold Separately: Promos, Spoilers, and Other Media Paratexts, New York: New York University Press.

Greenwald, Todd J., Murrieta, Peter, Cheung, Vince, and Montanio, Ben (executive producers 2007-2012), Wizards of Waverly Place, television series, Los Angeles: Disney Channel.

Hall, Carol (1987), 'Tween power: Youth's middle tier comes of age', Marketing \& Media Decisions, 22 October, p. 56.

Harris, Anita (2004), Future Girl: Young Women in the Twenty-First Century, London and New York: Routledge.

Hendershot, Heather (1998), Saturday Morning Censors, Durham: Duke University Press.

Jenkins, Henry (2006), Convergence Culture: Where Old and New Media Collide, New York: New York University Press. (2004), 'The cultural logic of media convergence', International Journal of Cultural Studies, 7:1, pp. 33-43. 
Blue, Morgan G. (Final Draft: June 2013)

Published with images in Film, Fashion \& Consumption Special Issue: TV \&

Fashion, Ed. Helen Warner, volume 2, number 1 (2013).

Johnson, Catherine (2012), Branding Television, London and New York: Routledge.

Johnson, Derek (2011), 'Devaluing and Revaluing Seriality: The gendered discourses of media franchising', Media, Culture and Society, 3:7, pp. 1077-93.

Kantrowitz, Barbara and Wingert, Pat (1999), 'The truth about tweens', Newsweek, http://newsweek.com/nw-srv/issue/16_99b/printed/us/so/so0116_1.htm. Accessed 19 October 1999.

Kearney, Mary Celeste (2004), 'Recycling Judy and Corliss: Transmedia exploitation and the first teen-girl production trend', Feminist Media Studies, 4:3, pp. 265-95.

Kellner, Douglas (1995), Media Culture: Cultural Studies, Identity, and Politics Between the Modern and the Postmodern, New York and London: Routledge.

Kinder, Marsha (1993), Playing with Power in Movies, Television, and Video Games:

From Muppet Babies to Teenage Mutant Ninja Turtles, Berkeley: University of California Press.

Kuhn, Annette (1985), The Power of the Image: Essays on Representation and Sexuality, London: Routledge. 
Blue, Morgan G. (Final Draft: June 2013)

Published with images in Film, Fashion \& Consumption Special Issue: TV \& Fashion, Ed. Helen Warner, volume 2, number 1 (2013).

Lemish, Dafna (1998), 'Spice girls' talk: A case study in the development of gendered identity', Millennium Girls: Today's Girls around the World, in S. A. Inness (ed.), Maryland: Rowman and Littlefield Publishers Inc., pp. 145-67.

Lewis, Lisa (1990), Gender Politics and MTV: Voicing the Difference, Philadelphia: Temple University Press.

Lipsitz, George (1992), 'The meaning of memory: Family, class, and ethnicity in early network television programs', Private Screenings: Television and the Female Consumer in L. Spigel and D. Mann (eds), Minneapolis: University of Minnesota Press, pp. 71-108.

Lotz, Amanda D. (2007), The Television Will Be Revolutionized, New York and London: Routledge.

Malik, Farah (2005), 'Mediated consumption and fashionable selves: Tween girls, fashion magazines, and shopping', Seven going on Seventeen: Tween Studies in the Culture of Girlhood, in C. Mitchell and J. Reid-Walsh (eds), New York: Peter Lang, pp. $257-77$.

Marmel, Steve, Robbins, Brian, Bridgett Sharla S., and Feldman, Michael (executive producers 2009-2011), Sonny with a Chance, television series, Los Angeles: Disney Channel. 
Blue, Morgan G. (Final Draft: June 2013)

Published with images in Film, Fashion \& Consumption Special Issue: TV \&

Fashion, Ed. Helen Warner, volume 2, number 1 (2013).

McAllister, Matthew P. and Giglio, Matt J. (2005), 'The commodity flow of U.S.

children's television', Critical Studies in Media Communication, 22:1, March, pp. 26-44.

McCarthy, Bonnie (2010), “'Sonny With a Chance” of buyers: Disney fashion goes from screen to store', Daily Finance, http:/www.dailyfinance.com/2010/07/31/sonny-with-achance-of-buyers-disney-fashion-goes-from-screen. Accessed 31 July 2010.

McRobbie, Angela (2009), The Aftermath of Feminism: Gender, Culture, and Social Change, London: SAGE.

(2007), 'Top girls? Young women and the post-feminist sexual contract', Cultural

Studies, 21: 4-5, July/September, pp. 718-37.

(1991), Feminism and Youth Culture: From Jackie to Just Seventeen, London:

Palgrave Macmillan.

Meehan, Eileen R. (1991), “"Holy Commodity Fetish, Batman!” The political economy

of the commercial intertext', The Many Lives of Batman, in R. E. Pearson and W.

Uricchio (eds.), New York: BFI-Routledge, pp. 47-65.

Minsky, Terri, Rogow, Stan, and Jansen Susan E. (executive producers 2001-2004),

Lizzie McGuire, television series, Los Angeles: Disney Channel. 
Blue, Morgan G. (Final Draft: June 2013)

Published with images in Film, Fashion \& Consumption Special Issue: TV \& Fashion, Ed. Helen Warner, volume 2, number 1 (2013).

Mitchell, Jamie (executive producer 2013-present), Sofia the First, television series, Los Angeles: Disney Channel.

Moseley, Rachel (2002), 'Glamorous witchcraft: gender and magic in teen film and television', Screen, 43:4, Winter, pp. 403-22.

Polikarpov, Yana (2009), 'From apparel to home décor, Disney revamps licensing biz', Adweek, 23 March, http://www.adweek.com/news/advertising-branding/apparel-home-dcor-disney-revamps-licensing-biz-105467. Accessed 20 May 2012.

Poryes, Michael, McNamara, Sean, Brookwell, David, Rinsler, Dennis, Warren, Marc, and Pearman, Raven-Symoné (executive producers 2003-2007), That's So Raven, television series, Los Angeles: Disney Channel.

Poryes, Michael and Peterman, Steven (executive producers 2006-2011), Hannah Montana, television series, Los Angeles: Disney Channel.

Probyn, Elspeth (2008), 'Troubling safe choices: Girls, friendship, constraint, and freedom', South Atlantic Quarterly 107:2, Spring, pp. 231-49.

Rose, Lacey (2012), ‘Disney channel's Gary Marsh on Tabloid Teen Stars, Marvel and the Junk Food Ban', The Hollywood Reporter, http://www.hollywoodreporter. 
Blue, Morgan G. (Final Draft: June 2013)

Published with images in Film, Fashion \& Consumption Special Issue: TV \&

Fashion, Ed. Helen Warner, volume 2, number 1 (2013).

com/news/disney-channel-gary-marsh-avengers-miley-cyrus-shia-labeouf-340251.

Accessed 21 June 2012.

Rose, Nikolas (1996), Inventing Our Selves: Psychology, Power and Personhood, New

York: Cambridge University Press.

Ross, Sharon Marie (2008), Beyond the Box: Television and the Internet, Australia:

Blackwell Publishing.

Stacey, Jackie (1991), 'Feminine Fascinations: Forms of identification in star-audience

relations' Stardom: Industry of Desire, in C. Gledhill (ed.), New York: Routledge, pp. $141-163$.

Street, Sarah (2001), Costume and Cinema: Dress Codes in Popular Film, London: Wallflower.

Thompson, Chris, Lotterstein, Rob, Straus, Jeff, and Conn, Eileen (executive producers 2010-present), Shake It Up, television series, Burbank and Hollywood: Disney Channel.

Walkerdine, Valerie (1998), 'Popular culture and the eroticization of little girls', in H. Jenkins (ed.), The Children's Culture Reader, New York: New York University Press, pp. 254-64. 
Blue, Morgan G. (Final Draft: June 2013)

Published with images in Film, Fashion \& Consumption Special Issue: TV \&

Fashion, Ed. Helen Warner, volume 2, number 1 (2013).

Warner, Helen (2009), 'Style over substance? Fashion, spectacle and narrative in

contemporary US television', Popular Narrative Media 2.2, pp. 181-193.

(2012), 'Tracing Patterns: Critical approaches to on-screen fashion', Film, Fashion

and Consumption 1:1, pp. 121-132. 